\title{
Are assemblages of the fireworm Hermodice carunculata enhanced in sediments beneath offshore fish cages?
}

\author{
Rodrigo Riera $^{1 * \#}$, Oscar Pérez ${ }^{1}$, Myriam Rodríguez $^{1}$, Eva Ramos ${ }^{1}$, Óscar Monterroso ${ }^{1}$ \\ ${ }^{1}$ Centro de Investigaciones Medioambientales del Atlántico (CIMA SL), Arzobispo Elías Yanes 44, 38206 La \\ Laguna, Tenerife, Canary Islands, Spain
}

Received 17 March 2012; accepted 9 June 2013

(CThe Chinese Society of Oceanography and Springer-Verlag Berlin Heidelberg 2014

\begin{abstract}
Abundances of the fireworm Hermodice carunculata were counted through a monitoring assessment study of fish cages in Barranco Hondo (NE Tenerife). Seven campaigns were conducted from November 2007 to June 2010 and temporal variations were found, as well as differences among sampling stations. The polychaete $H$. carunculata obtained its highest abundance in sediments beneath fish cages throughout the study period. Thus, the assemblages of this omnivorous species were favoured by the presence of fish cages.

Key words: aquaculture, organic enrichment, environmental impact, Polychaeta, Hermodice carunculata, Tenerife, Canary Islands, Atlantic Ocean
\end{abstract}

Citation: Rodrigo Riera, Oscar Pérez, Myriam Rodríguez, Eva Ramos, Óscar Monterroso. 2014. Are assemblages of the fireworm Hermodice carunculata enhanced in sediments beneath offshore fish cages?. Acta Oceanologica Sinica, 33(4): 108-111, doi: 10.1007/s13131-014-0449-y

\section{Introduction}

In the Canary Islands, offshore aquaculture has grown exponentially during the past decade, with an overall production of $7250 \mathrm{t}$ in 2010 (21\% of overall national production) (APROMAR, 2010). Marine fish farming production is focused on sea bream (Sparus aurata) and sea bass (Dicentrarchus labrax) and feeding proceeds with dry pellets in both species. Fish faeces and uneaten pellets from fish cages sink to the seabed (Cromey et al., 2002), although an important part is consumed by wild fish (Fernández-Jover et al., 2008). The most important environmental impact of fish cages on seabeds is the accumulation of organic matter, which turns into a hypoxic or even anoxic sediment (Holmer et al., 2003).

As occurs in the Mediterranean Sea, the Canarian archipelago is characterized as oligotrophic with low productivity (Braun et al., 1985; Davenport et al., 2002). Thus, microbial and infaunal assemblages are highly dependent on organic matter inputs, like particulate material from fish cages. This results in the proliferation of abundant and diverse infaunal assemblages and the presence of dense fish populations in the vicinity of fish cages (Boyra et al., 2004).

In several fish cages of the Canary Islands, aggregates of the bearded fireworm, Hermodice carunculata, have been observed in sediments beneath cages (Monterroso et al., 2004). In tropical and subtropical areas, this amphinomid polychaete is an important omnivore of a wide range of prey (e.g., zoanthids, anemones, gorgonians, milleporid hydrocorals) (Witman, 1988), but there is no previous information on interactions of this species with aquaculture activities.

The main aim of the present study was to check if the presence of offshore fish cages was correlated with $H$. carunculata abundance in an oligotrophic subtropical area, like the Canarian archipelago.

\section{Materials and methods}

Hermodice carunculata counts were carried out in Barranco Hondo (NE Tenerife coordinates $28^{\circ} 22^{\prime} 53^{\prime \prime} \mathrm{N} / 16^{\circ} 21^{\prime} 09^{\prime \prime} \mathrm{W}$ ) during environmental monitoring assessment of fish cages. Sea bream (Sparus aurata) and European sea bass (Dicentrarchus labrax) were cultured in the studied fish farm cages. The fish farm consisted of one group of four fish cages with an annual production of about $200 \mathrm{t}$. Fishes were fed manually using commercial, pelleted, and extruded diets with an average nutrient content (on a dry weight basis) of $48 \%$ protein, $19.5 \%$ fat, $22 \%$ carbohydrate, $7.9 \%$ nitrogen, and $1.08 \%$ phosphorus. Pellet size ranged from 2-7 mm diameter and fish were fed at an average of about $2 \%$ (biomass/day), with a food conversion ratio of 1.5-1.6. Each fish cage had a diameter of $20 \mathrm{~m}$ and reached a depth of $10 \mathrm{~m}$. Fish cages were installed on seabeds at $28-30 \mathrm{~m}$ depth, where the temperature throughout the year ranged from $18^{\circ} \mathrm{C}$ (January) to $22^{\circ} \mathrm{C}$ (September). Continuous currents are present throughout the year in the study area, with southwest (36.4\%) and northwest (27.8\%) directions, and mean values of $12-14 \mathrm{~cm} / \mathrm{s}$ on the surface and $20-22 \mathrm{~cm} / \mathrm{s}$ on the seabed layer (unpublished data). The benthic habitat was mainly comprised of sandy bare seabeds and Cymodocea nodosa seagrass meadows were located within the surroundings of the studied fish cages (350-400 m). No rocky substrates were present in the study area and there were apparently no signs of organic enrichment (e.g., Beggiatoa mats, black azoic sediments) beneath the studied fish cages.

Four stations (CAL-1, CAL-2, CAL-3, and CAL-4) were sampled, located beneath the fish cage (CAL-3), in the surroundings (400-500 m) (CAL-2 and CAL-4), and far from fish cages $(>1.5 \mathrm{~km}$ ) (CAL-1) (Fig. 1). Three transects of $20 \mathrm{~m}$ long and $2 \mathrm{~m}$ wide were established within each station to count H. carunculata numbers. Each transect was $5 \mathrm{~m}$ apart from each other.

\footnotetext{
*Corresponding author, E-mail: rodrigo@cimacanarias.com

\#Current address: Department of Biodiversity, Qatar Environment and Energy Research Institute (QEERI), 5825 Doha, Qatar
} 


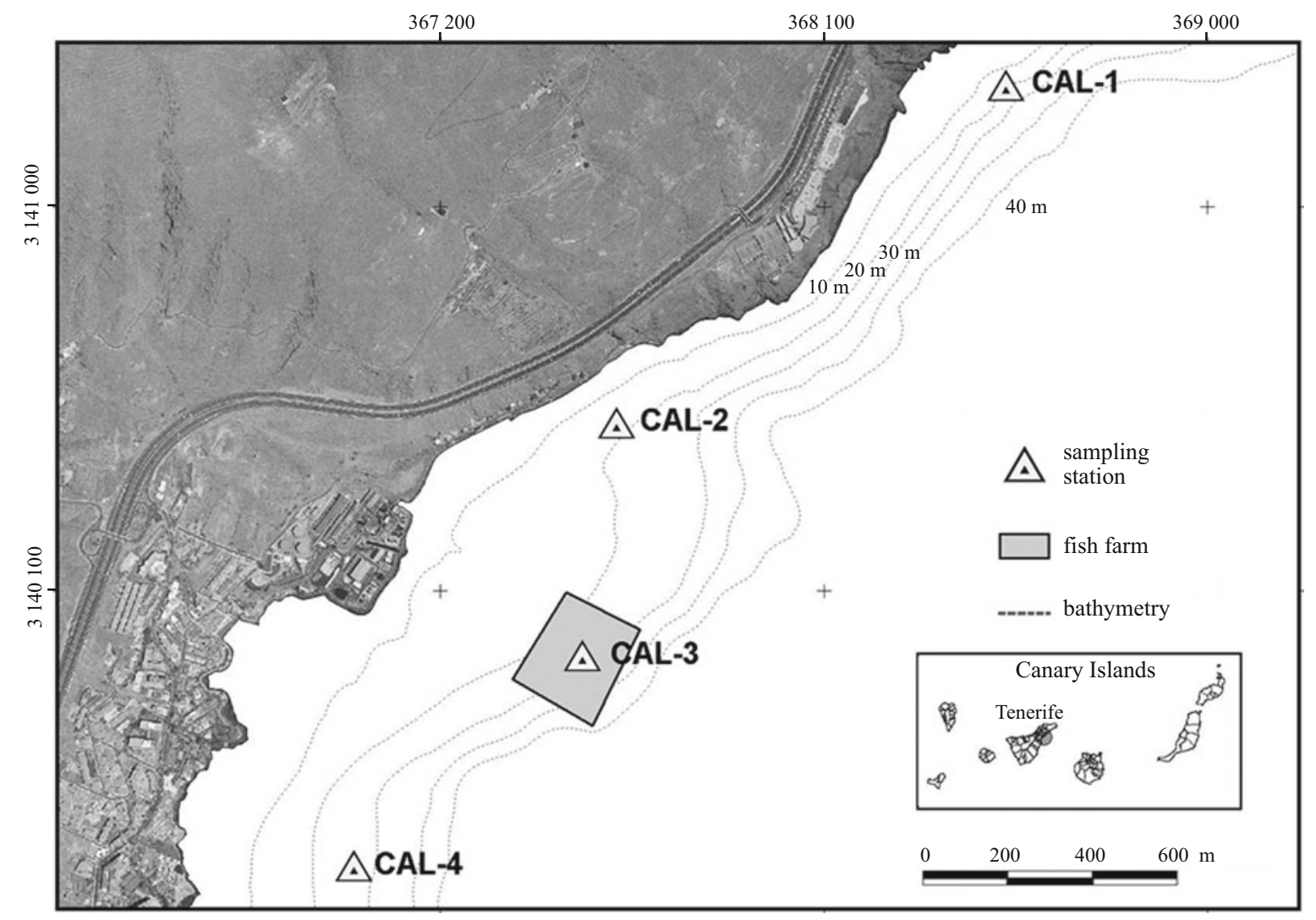

Fig.1. Map of the study area showing sampling stations and fish cage lease.

Individuals of $H$. carunculata were counted throughout seven sampling campaigns (November 2007, March 2008, June 2008, September 2008, December 2008, April 2009, and June 2010).

Differences in Hermodice carunculata abundances among sampling stations throughout the study period were tested by means of analysis of variance (ANOVA) that included the factors "Campaign" ( $C$, random factor) and "Station" ( $S$, fixed factor). Data from each sampling station were then pooled among the three transects to facilitate data analysis. Data were square-root transformed and no data standardisation was done. Despite variances that remained heterogeneous in all cases, we avoided an increase in type I error by reducing the $\alpha$-value to a 0.01 level (Underwood, 1991); ANOVA is robust to such departures for balanced studies. Post-hoc tests were used, when appropriate, to resolve differences among levels of significant factors.

\section{Results}

A total of 4972 individuals of Hermodice carunculata were found throughout the seven sampling campaigns conducted during the study period (2007-2010). The highest abundances of $H$. carunculata $(460.33 \pm 60.45$ individuals from the three transects) were found in sediments beneath fish cages in December 2008, but this species was absent from station CAL-2 in November 2007 (Table 1, Fig. 2).

The abundances of Hermodice carunculata varied significantly among campaigns $(F=24.63, p=0.0002$, Table 2$)$, as well as sampling stations $(F=7.19, p=0.003$, Table 2$)$. Moreover, these differences were significant throughout the study period (November 2007-June 2010) among sampling stations $(C \times S, F=18.47, p=0.0002$, Table 2). Post-hoc tests showed that $H$. carunculata abundances in sediments beneath fish cages were significantly higher than the remaining sampling stations (CAL-1, CAL-2, and CAL-4) not affected by fish cages (Table 3).

\section{Discussion}

Data presented showed that abundances of the fireworm, Hermodice carunculata, assemblages were related to the presence of fish cages. This species acts as an omnivore and con-

Table 1. Mean abundances ( \pm SE) of Hermodice carunculata at sampling stations throughout the study period

\begin{tabular}{lccccccc}
\hline \multicolumn{1}{c}{ Station } & Nov. 7 & \multicolumn{1}{c}{ Mar. 8} & Jun. 8 & Sep. 8 & Dec. 8 & Apr. 9 \\
\hline CAL-1 (control) & $48.33 \pm 16.62$ & $38.00 \pm 3.61$ & $3.67 \pm 4.62$ & $32 \pm 13$ & $16.33 \pm 4.51$ & $18.00 \pm 11.27$ & $12.33 \pm 0.58$ \\
CAL-2 (influenced) & 0 & $77.67 \pm 19.55$ & $8.67 \pm 3.06$ & $23.67 \pm 6.66$ & $45.00 \pm 9.64$ & $44.33 \pm 37.61$ & $68.67 \pm 16.26$ \\
Fish cages & $118.00 \pm 6.93$ & $32.67 \pm 1.53$ & $88.00 \pm 50.32$ & $75 \pm 21$ & $460.33 \pm 60.45$ & $179.33 \pm 73.33$ & $86.33 \pm 41.19$ \\
CAL-4 (influenced) & $8.67 \pm 2.08$ & $37.67 \pm 14.36$ & $11.33 \pm 5.69$ & $29.33 \pm 5.13$ & $62.67 \pm 15.01$ & $10.33 \pm 6.66$ & $21.00 \pm 4.58$ \\
\hline
\end{tabular}




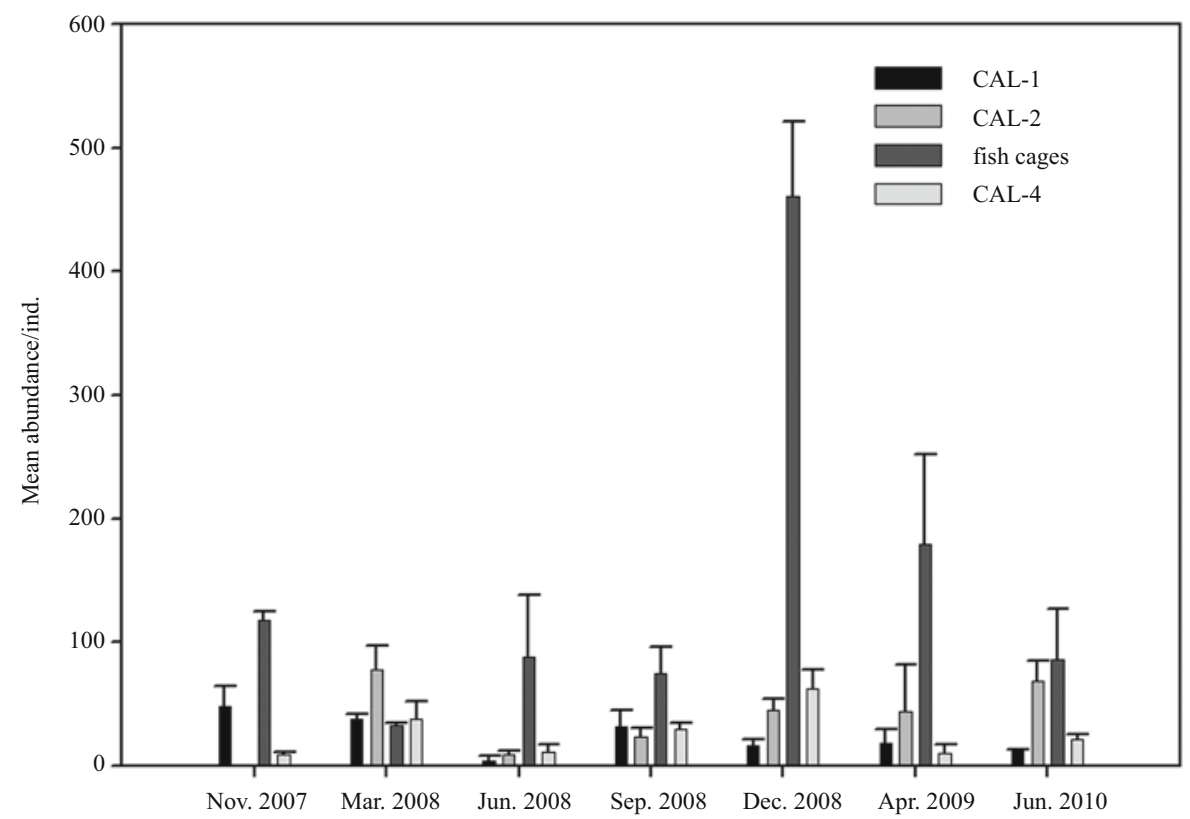

Fig.2. Mean abundances ( \pm SE) of Hermodice carunculata throughout sampling campaigns.

Table 2. Results of ANOVA testing for differences in Hermodice carunculata abundances with varying proximity from the fish cages ("Station", fixed factor) throughout the study period ("Campaign", fixed factor)

\begin{tabular}{cccccc}
\hline Source of variation & df & SS & MS & $p$ \\
\hline Campaign $(C)$ & 6 & 231.61 & 38.60 & 24.63 & 7.19 \\
Station $(S)$ & 3 & 624.89 & 208.30 & 18.47 \\
$C \times S$ & 18 & 520.95 & 28.94 & 0.003 \\
Residual & 56 & 87.75 & 1.57 & 0.0002 \\
Total & 83 & 1465.21 & & \\
\hline
\end{tabular}

Notes: $P$-values denote significant values $(p<0.01)$. df represents degrees of freedom, SS sum of squares and MS mean of squares.

Table 3. Post-hoc tests of Hermodice carunculata abundances among sampling stations throughout the study period

\begin{tabular}{ccc}
\hline Groups & $t$ & $p$ \\
\hline CAL1-CAL2 & 0.612 & 0.572 \\
CAL1-Cages & 3.248 & 0.002 \\
CAL1-CAL4 & 0.186 & 0.852 \\
CA2-Cages & 2.569 & 0.012 \\
CAL2-CAL4 & 0.475 & 0.627 \\
Cages-CAL4 & 3.148 & 0.002 \\
\hline
\end{tabular}

Notes: CAL1 represents control and CAL2 and CAL4 influenced stations.

sumes fish faeces and uneaten pellets deposited in sediments beneath fish cages. However, large assemblages of $H$. carunculata were recorded prior to the presence of fish cages, possibly due to sewage effluent in the study area.

Monterroso et al. (2004) found aggregates of this polychaete in sediments beneath fish cages during the first monitoring campaigns (2003) in Igueste de San Andrés Bay (NE Tenerife), however, they were not present in later sampling campaigns. Unfortunately, a specific sampling design to count Hermodice individuals was not conducted in former fish cages.
One of the main reasons for these variations of $H$. carunculata assemblages was drastic changes in aquaculture feeding regime in the study area. After a peak of $H$. carunculata abundances in December 2008, detailed supervision and profitable aquaculture feeding regimes were carried out by the aquaculture company, and consequently a minimisation of environmental perturbations from aquaculture activities was found in sediments beneath cages. Thus, no signs of organic enrichment (mainly uneaten pellets) in sediments beneath fish cages were found and no proliferation of $H$. carunculata individuals was encountered afterwards. Moreover, another partial explanation of high abundances of $H$. carunculata in winter periods is seasonal variation of this species, which is attracted to organic enriched sediments beneath the cages in periods with low primary production.

\section{Acknowledgements}

To the company Cultivos Marinos del Atlántico SL for logistic facilities and financial support throughout the present study. We are also grateful to the remaining staff of CIMA SL that helped in one way or another during sampling campaigns. To Dr. F. Tuya (BIOGES, University of Las Palmas de Gran Canaria) for interchange of ideas and constructive comments on data analysis. 


\section{References}

APROMAR. 2010. La acuicultura marina de peces en España. Technical report 2010. Cádiz: APROMAR, 69

Boyra A, Sánchez-Jerez P, Tuya F, et al. 2004. Attraction of wild coastal fishes to an Atlantic subtropical cage fish farms, Gran Canaria, Canary Islands. Environmental Biology of Fishes, 70(4): 393-401

Braun J G, Orzáiz I, de Armas J D, et al. 1985. Productividad y biomasa del ultraplancton, nanoplancton y fitoplancton de red en aguas de las Islas Canarias. Boletín del Instituto Español de Oceanografía, 2(1): 192-204

Cromey C J, Nickell T D, Black K D. 2002. DEPOMOD-modelling the deposition and biological effects of waste solids from marine cage farms. Aquaculture, 214: 211-239

Davenport R, Never S, Helmke T, et al. 2002. Primary production in the northern Canary islands region as inferred from Seawifs imagery. Deep Sea Research II, 49: 3481-3496

Fernández-Jover D, Sánchez-Jérez P, Bayle-Sempere J T, et al. 2008.
Seasonal patterns and diets of wild fish assemblages associated to Mediterranean coastal fish farms. ICES Journal of Marine Science, 65: 1153-1160

Holmer M, Duarte C, Heilskov A, et al. 2003. Biogeochemical conditions in sediments enriched by organic matter from net-pen fish farms in the Bolinao area, Philippines. Marine Pollution Bulletin, 46: $1470-1479$

Monterroso O, Núñez J, Riera R. 2004. Macrofauna de fondos blandos en las concesiones de acuicultura de la bahía de Igueste de San Andrés. Revista de la Academia Canaria de Ciencias, 15(3-4): $77-86$

Underwood A J. 1991. Beyond BACI: experimental designs for detecting human impacts on temporal variations in natural populations. Australian Journal of Marine and Freshwater Research, 42: 569-587

Witman J D. 1988. Effects of predation by the fireworm Hermodice carunculata on milleporid hydrocorals. Bulletin of Marine Science, 42(3): 446-458 